\title{
The fossil shrew Cretasorex arkhangelskyi Nessov et Gureev, 1981 from Uzbekistan - the systematic position among Soricidae, taxonomic status and geological age
}

\author{
Alexey V. Lopatin \& Alexey S. Tesakov \\ ABSTRACT. Cretasorex arkhangelskyi Nessov et Gureev, 1981 was described from the Upper Cretaceous \\ of Uzbekistan as the earliest member of Soricidae. Later, it was reevaluated as the Late Cenozoic soricid. The \\ reexamination of the holotype demonstrates the reference of this soricid to the tribe Soricini, and, more \\ specifically, the group of Sorex s.l. Indirectly it suggests an age not older than Late Miocene. The separate \\ generic rank is possible for this form.
}

KEY WORDS: Cretasorex arkhangelskyi, Soricini, Soricidae, Insectivora, Uzbekistan, Late Cenozoic.

AlexeyV.Lopatin [alopat@paleo.ru], Paleontological Institute of the Russian Academy of Sciences, Profsoyuznaya ul.123, Moscow 117647, Russia; AlexeyS.Tesakov [tesak@ginras.ru], Geological Institute of the Russian Academy of Sciences, Pyzhevskiy per. 7, Moscow 119017, Russia.

\section{Ископаемая землеройка Cretasorex arkhangelskyi Nessov et Gureev, 1981 из Узбекистана - систематическое положение среди Soricidae, таксономический статус и геологический возраст}

\begin{abstract}
А.В. Лопатин, А.С. Тесаков
РЕЗЮМЕ. Переизучение голотипа Cretasorex arkhangelskyi Nessov et Gureev, 1981, описанного из верхнего мела Узбекистана и позже считавшегося позднекайнозойским представителем Soricidae, показало, что эта форма должна рассматриваться в пределах трибы Soricini и близка к группе Sorex s.1. Косвенно это может указывать, что возраст этой находки не древнее позднего миоцена.Cretasorex может иметь самостоятельный родовой статус.
\end{abstract}

КЛЮЧЕВЫЕ СЛОВА: Cretasorex arkhangelskyi, Soricini, Soricidae, Insectivora, Узбекистан, поздний кайнозой.

\section{Introduction}

Cretasorex arkhangelskyi was originally described by Nessov \& Gureev (1981) based on the single edentulous mandibular fragment from the locality Dzharakuduk (=Bissekty) in the central Kyzylkum Desert, Uzbekistan. The fossiliferous layer was cited as the upper part of the Taikarshi Member, dated as upper Turonian-Santonian, Upper Cretaceous. Later, Nessov $(1990,1997)$ attributed these deposits to the Bissekty Formation and dated the level where this soricid fragment come from as possibly Coniacian. According to the current geological research these deposits belong to the Bissekty Member of the Kendyktyube Formation, which is dated as middle-upper Turonian (Averianov \& Archibald, 2003).

The Cretasorex was treated as the earliest member of Soricidae (Nessov \& Gureev, 1981, 1982) or Placentalia indet. (McKenna \& Bell, 1997).

Nessovet al. (1994), Nessov (1997) and Storchet al. (1998: 94) argumented that the holotype represents a soricine of modern appearance (with deeply pocketed internal temporal fossa and well-separated facets of the articular condyle) and it is possibly not contemporaneous with the Late Cretaceous deposits. Nessov et al. (1994: 56-57) supposed that this fossil may represent a contaminant of Late Cenozoic age from paleoburrow infilling.

McKenna \& Bell (1997: 81) noted the following: "Nessov (Nesov) and Gureev (Gureyev) believed this almost indeterminate animal to a Cretaceous shrew because of the pocketed coronoid process of the mandible. However, such a structure occurs in some mammals that lack a zygomatic arch, e.g. in certain apternodontids. Cretasorex is apparently not referable to either Sorex or to Diplomesodon, both of which are currently resident in the Kyzyl Kum area where Cretasorex was found. That the animal actually represents a shrew remains to be proven... If truly a shrew, its collection from a "paleoburrow" infilling suggests a late Cenozoic but not necessarily Recent age."

We reinvestigated the holotype ofCretasorex arkhangelskyi, housed at the Museum of Central Research 


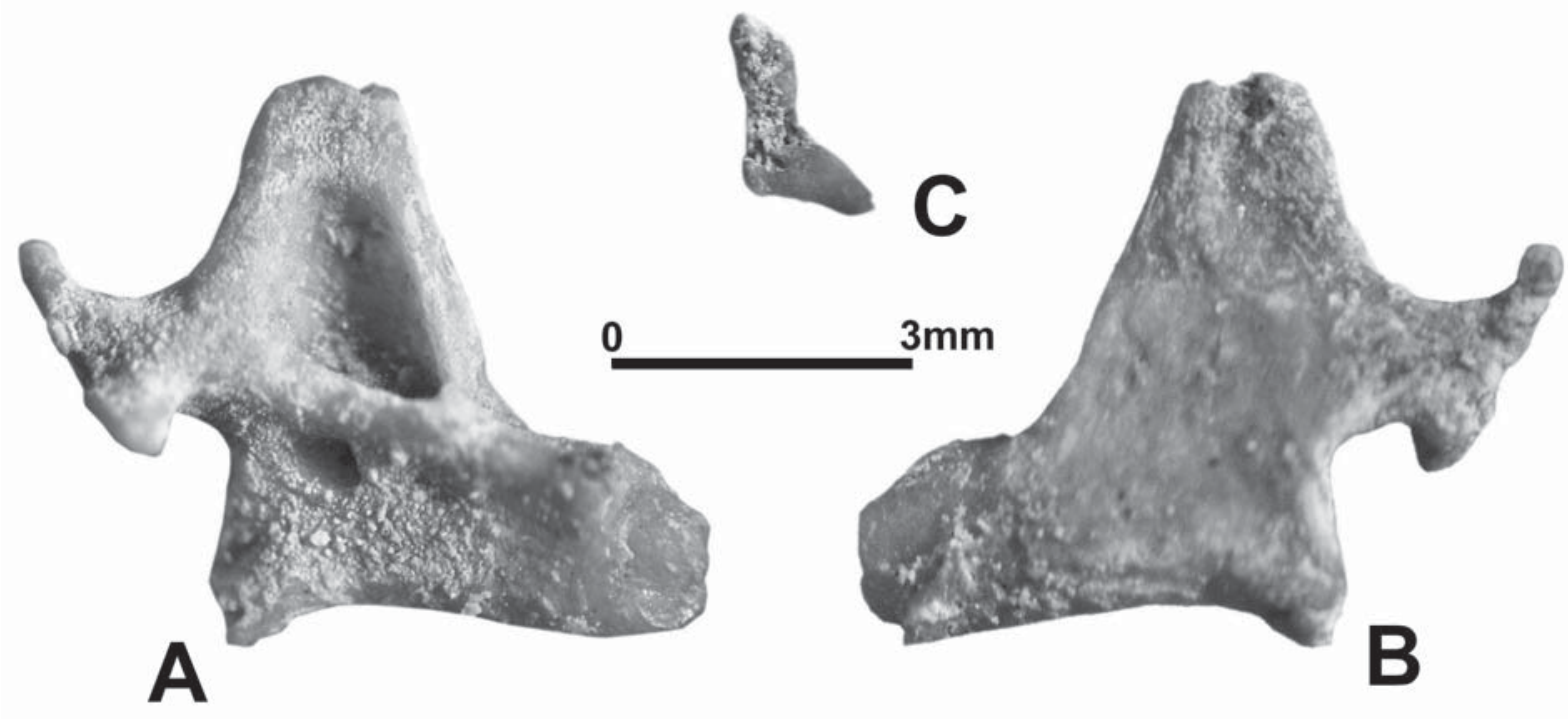

Figure 1. Cretasorex arkhangelskyi Nessov et Gureev, 1981. CNIGR Museum, 2/11758, holotype, edentulous fragment of the left dentary with nearly preserved ascending ramus. Dzharakuduk (=Bissekty), Central Kyzylkum Desert, Uzbekistan. Upper Cenozoic.

A - lingual view, B - labial view, C - view of articular surface of the condyle.

Geological Institute (CNIGR Museum), Saint-Petersburg. The present paper reports the results of our study and conclusions about the systematic position, taxonomic status, and supposed geological age of this fossil.

\section{Systematic Paleontology}

Family Soricidae Fischer, 1817

Subfamily Soricinae Fischer, 1817

Tribe Soricini Fischer, 1817

Genus Cretasorex Nessov et Gureev, 1981

Cretasorex arkhangelskyi Nessov et Gureev, 1981 Fig.1.

Cretasorex arkhangelskyi: Nessov \& Gureev, 1981: 1003, fig. 1; Nessov, 1981: fig. 11,30; Nessov, 1982: pl.2, fig.6; Nessov, 1985: 213, pl.2, fig.4; Nessov et al., 1994: 56, pl.1, fig.3.

Holotype. CNIGR Museum, 2/11758, edentulous fragment of the left dentary with nearly preserved ascending ramus.

Type locality. Dzharakuduk (=Bissekty), Central Kyzylkum Desert, Uzbekistan.

Stratigraphic level. Tentatively, Upper Cenozoic.

Description. A shrew of medium size. Judging from the preserved part, the posterior part of the horizontal ramus is rather massive and deep. The large alveolus of the posterior root of the last molar indicates the well developed talonid. No more than two of its antero-posterior diameters separate this alveolus from the base of the coronoid process.

The anterior edge of the coronoid process is slightly posteriorly sloped. The upper part of the lateral side of the coronoid bears a distinct external temporal fossa, which takes about two thirds of the length of the process. The lower margin of the fossa is located at the level of the upper edge of the condyle neck. The lateral surface of the ramus below the fossa is even. The apex of the coronoid is not preserved. Thus the presence of the spicule cannot be proved.
The internal temporal fossa is extensive and deeply pocketed. The medial ridge under the fossa overhangs the region of the mandibular foramen. This foramen is large. Its anterior end is located at the level of the mid length of the fossa.

The upper incisure (the one between the coronoid and the articular processes) is deep and broad because the neck of the condyle is rather elongated. The condyle shows a distinct lingual emargination and nearly straight labial side. The condyle has two articular facets separated by slightly compressed and stretched interarticular area. The upper facet is not large, rounded, and lingually sloped. The lower facet is broad, semi-oval in shape, ventrolingually tilted, and lingually pointed. In the general appearance the condyle is gracile, asymmetrical, vertically extended, with distinct ventrolingual protrusion. The lower incisure is extensive.

The base of the angular process is massive, and posteroventrally directed. The lower curvature of the ascending ramus is moderately expressed.

Measurements. See Nessov \& Gureev (1981) and Fig. 1. The comparison with modern Sorex araneus L. shows nearly equal size class of these shrews.

Occurrence. The type locality.

\section{Discussion}

The type specimen of Cretasorex arkhangelskyi is the mandibular fragment with mostly preserved ascending ramus (Fig. 1). The latter demonstrates the absence of a masseter fossa, the presence of a deep internal pocket and clearly divided condylar facets. Thus, firstly, Cretasorex belongs to Soricinae. It is not a zalambdodont soricomorph apternodontid likeOligoryctes, which has the deeply pocketed internal fossa in combination of the single articular facet of the mandibular condyle (Asher et al., 2002). It is not a nyctitheriid, and soricolestine or heterosoricine soricid, which have an as- 
cending ramus with a well developed masseter fossa and without an internal pocket (see Sigé, 1976 for Nyctitheriidae; Lopatin, 2002 for Soricolestinae; and Viret \& Zapfe, 1951; Engesser, 1975 for Heterosoricinae).

The structure of the condyle, with distinct lingual emargination, the lacking labial emargination, and absence of a constriction of the interarticular region, suggests that Cretasorex is not attributable to Crocidosoricinae, Crocidurinae, Limnoecinae, Allosoricinae, and further not to soricine tribes Anourosoricini, Beremendiini, Blarinellini, Blarinini, Neomyini, and Notiosoricini (Repenning, 1967; Gureev, 1971, 1979; Crochet, 1975; Reumer, 1984, 1998; Ziegler, 1989). The above cited morphology suggests that Cretasorex is the true representative of the tribe Soricini (Repenning, 1967; Reumer, 1984, 1998). Moreover, it is close to the group of Sorex s.l. in shape of the articular facets and interarticular area. However, it is distinct in the gracile general appearance of the articular surface of the condyle and in the strongly extended lower facet. Therefore, we cannot attribute Cretasorex to Sorex s.l. or to any other soricine genus, as well. As a conclusion, we preserve the genus level status for Cretasorex.

The assignment of Cretasorex to the Cretaceous can be ruled out on the basis of the recent discovery of the earliest evolutionary stage of shrews in Paleogene of Asia (Lopatin, 2002). It is very likely that the fossil in question represents a late Cenozoic contamination. Averianov (personal communication) reported the finding of the tarsometatarsus of the Pliocene partridge Plioperdix sp. in the Bissekty Member. Apparently, it is similar case of the contamination. The morphologic similarity of Cretasorex and Sorex s.1. may indirectly suggest an age not older than Late Miocene.

ACKNOWLEDGEMENTS. We thank the administration of the CNIGR Museum for the easy access to the holotype of Cretasorex arkhangelskyi, A.O. Averianov and M.V. Zaitsev (Zoological Institute RAS, St.-Petersburg) and V.S. Zazhigin (Geological Institute RAS, Moscow), and especially N.N. Kalandadze (Paleontological Institute RAS, Moscow) for stimulating discussion and useful comments. The work was supported by the Russian Foundation of Basic Research, projects 02-04-48458, 04-04-49637, 04-05-64805 (AL), and 02-05-64126 (AT); the grants of the President of the Russian Federation, projects MK-726.2004.4 and NSh-1840.2003.4; and the grant of the Program of the Presidium of the Russian Academy of Sciences "Support of Young Scientists", 2001 (AL).

\section{References}

Asher R.J., McKenna M.C., Emry R., Tabrum A.R. \& Kron D.G. 2002. Morphology and relationships of Apternodus and other extinct, zalambdodont, placental mammals // Bulletin of the American Museum of Natural History. No.273. P.1-117.

Averianov A.O. \& Archibald J.D. 2003. Mammals from the Upper Cretaceous Aitym Formation, Kyzylkum Desert, Uzbekistan// Cretaceous Research. Vol.24. No.2. P.171191.
Crochet J.-Y. 1975. Diversité des insectivores soricidés du Miocène inférieur de France // Colloque International C.N.R.S. No.218. P.631-652.

Engesser B. 1975. Revision der europäischen Heterosoricinae (Insectivora, Mammalia) // Eclogae Geologicae Helvetiae. Vol.68. No.3. P.649-671.

Gureev A.A. 1971. [Shrews (Soricidae) of the Fauna of the World]. Leningrad: Nauka. 254 p. [in Russian].

Gureev A.A. 1979. [The Fauna of the USSR. Mammals. T.4. Vyp.2. Insectivores (Mammalia, Insectivora). Hedgehogs, Moles, and Shrews (Erinaceidae, Talpidae, Soricidae)]. Leningrad: Nauka. 503 p. [in Russian].

Lopatin A.V. 2002. The earliest shrew (Soricidae, Mammalia) from the Middle Eocene of Mongolia // Paleontological Journal. Vol.36. No.6. P.650-659.

McKenna M.C. \& Bell S.K. 1997. Classification of Mammals Above the Species Level. New York: Columbia University Press. $631 \mathrm{p}$.

Nessov L.A. 1981. [Cretaceous salamanders and frogs of Kizylkum Desert] // Trudy Zoologicheskogo Instituta AN SSSR. T.101. P.57-88 [in Russian].

Nessov L.A. 1982. [The ancient mammals of the USSR] // Ezhegodnik Vsesoyuznogo Paleontologicheskogo Obshchestva. T.25. P.228-242 [in Russian].

Nessov L.A. 1985. [Rare bony fishes, terrestrial lizards and mammals from zone of estuaries and coastal plains of the Cretaceous of Kizylkum] // Ezhegodnik Vsesoyuznogo Paleontologicheskogo Obshchestva. T.28. P.199-219 [in Russian].

Nessov L.A. 1990. [Small ichthyornithiform bird and other bird remains from Bissekty Formation (Upper Cretaceous) of Central Kyzylkum Desert] // Trudy Zoologicheskogo Instituta AN SSSR. T.210. P.59-62 [in Russian].

Nessov L.A. 1997. [Cretaceous Nonmarine Vertebrates of Northern Eurasia] / Golovneva L.B. \& Averianov A.O. (eds.). Sankt-Peterburg: Izdatel'stvo Sankt-Peterburgskogo Universiteta. 218 p. [in Russian].

Nessov L.A. \& Gureev A.A. 1981. [The finding of the jaw of the earliest shrew from the Upper Cretaceous of the Kyzylkum Desert] // Doklady Akademii Nauk SSSR. T.257. No.4. P.1002-1004 [in Russian].

Nessov L.A. \& Gureev A.A. 1982. [On the time of the origin of the several characters of the morphology of the Soricidae] // [Third Congress of the All-Union Theriological Society. Abstracts of Papers]. Moskva: Teriologicheskoe Obshchestvo. T.1. P.60-61 [in Russian].

Nessov L.A., Sigogneau-Russell D. \& Russell D.E. 1994. A survey of Cretaceous tribosphenic mammals from Middle Asia (Uzbekistan, Kazakhstan and Tajikistan), of their geological setting, age and faunal environment // Palaeovertebrata. Vol.23. No.1-4. P.51-92.

Repenning C.A. 1967. Subfamilies and genera of the Soricidae // United States Geological Survey Professional Paper. No.565. P.1-74.

Reumer J.W.F. 1984. Ruscinian and Early Pleistocene Soricidae (Insectivora, Mammalia) from Tegelen (The Netherlands) and Hungary // Scripta Geologica. No.73. P.1173.

Reumer J.W.F. 1998. A classification of the fossil and recent shrews // Wójcik J.M. \& Wolsan M. (eds.). Evolution of 
Shrews. Białowieża: Mammal Research Institute, Polish Academy of Sciences. P.5-22.

Sigé B. 1976. Insectivores primitifs de l'Éocène supérieur et Oligocène inférieur d'Europe occidentale. Nyctithériidés // Mémoires du Muséum National d'Histoire Naturelle, Séries C. T.34. P.1-140.

Storch G., Qiu Zh. \& Zazhigin V.S. 1998. Fossil history of shrews in Asia // Wójcik J.M. \& Wolsan M. (eds.).
Evolution of Shrews. Białowieża: Mammal Research Institute, Polish Academy of Sciences. P.93-120.

Viret J. \& Zapfe H. 1951. Sur quelques Soricidés miocènes // Eclogae Geologicae Helvetiae. Vol.44. No.2. P.411-426. Ziegler R. 1989. Heterosoricidae und Soricidae (Insectivora, Mammalia) aus dem Oberoligozän und Untermiozän Süddeutschlands // Stuttgarter Beiträge zur Naturkunde, Serie B: Geologie und Paläontologie. No.154. S.1-73. 